\title{
Mathematics Education Problems and Attempts to Solve Them in Nowadays Lithuanian School
}

\author{
*Ieva Malaukytè \\ Aleksandras Stulginskis University, Centre of Mathematics, Physics and Information Technology, \\ Universiteto Street 10, Akademija, Kaunas region, LT-53361, Lithuania
}

\begin{abstract}
The decreasing number of the Lithuanian residents has strong impact on the educational system: the number of pupils is decreasing, the schools are getting closed. School is considered to be the provider of educational services, so it is necessary to search, how to preserve and attract clients - pupils. The growing competition induces search for distinctiveness among the schools. According to the theory of generations of William Strauss and Neil Howe, now we have to educate representatives of generation Z, who do not like violence, restrictions, want to be distinctive and are open to the world of technologies. The teacher faces the challenge when s/he wants to convey mathematical skills to these pupils. The profile teaching followed by training based on individual curricula provided more choices for the pupils. This freedom led to the dead-end of mathematical literacy and forced to return to a compulsory national final exam of Mathematics and to change the indexes for the persons entering studies of the first cycle and integrated studies. In the article, mathematics achievements and situation in schools in Lithuania as well as the measures taken to improve mathematical literacy in the country are described.
\end{abstract}

Key words: school, teaching, generation $Z$, mathematics, exam.

\section{Introduction}

The Lithuanian demographic situation has changed so much in the recent decades that the birthrate cannot ensure change of generations. The number of residents is decreasing not only because of negative tendencies of natural shift (birth-rate, mortality) but also because of emigration. The number of school-age children is not so big to fill all the school operating 7 years ago, so the issue of closing the small schools has been relevant for several consecutive years. The teachers become unemployed, pupils have to select other educational institutions and schools are regarded as providers of educational services. All of these things have turned into causes of inter-school competition. Each school tries to find modes how to become distinctive and attractive for pupils and their parents.

According to the theory of generations of the American scientists Neil Howe and William Strauss, it is considered that a unique generation of people grows every 20 years. It is formed by crises, rises and burst of technologies of that period, which determines the world outlook and personal values of people (Strauss \& Howe, 1992). Now the schools have children of generation $\mathrm{Z}$. The educational institutions should take into account the particularities characteristic to the generation $\mathrm{Z}$ and model the (self) education of this generation appropriately in order to achieve better learning results: to apply newer and more advanced teaching methods, which would cause interest and motivate to study (Alonderiné, 2015; Targamadzè, 2014; Pečiuliauskienè, Valantinaitè \& Malonaitienè, 2013; Math teachers experience, 2002). Several different series of textbooks meant to teach Mathematics are offered. The question arises which textbook could help to achieve the best result of mathematical skills to implement the programme of secondary education of Mathematics most successfully, and to prepare the senior pupils for the national final exam of Mathematics properly. If something is wrong in the sector of general education, it affects the system of higher education later because the pupils become the members of university or college communities in several years.

\footnotetext{
* Corresponding Author's email: ieva.malaukyte@asu.lt
} 
The profile training was started in 2000. Later it was replaced by individual curricula, which allowed the pupils to choose the subjects and national exams. The pupils have been using the possibility to avoid bigger number of lessons of Mathematics and exam of Mathematics for many years. The Ministry of Education noticed this problem and took the complaints of higher educational schools into account, and thus in 2016 the national final exam of Mathematics became compulsory for pupils, who want to study in the State-funded places.

The aim of studies is to show how the number of students has changed in Lithuania, the number of schools and education policy; how it was influenced by the emergence of a larger supply of different types of schools, as affected the level of mathematics knowledge and what measures are applied to increase mathematics literacy.

\section{Materials and Methods}

I want to disclose the impact of decreasing number of pupils and orders of the Ministry of Education on the schools, mathematical education and results of national final exam of Mathematics. My respondents were Lithuanian schools, pupils, results of the national final exam of Mathematics, orders of the Ministry of Education and Science.

The data of 7 years from the Lithuanian Statistics Department (number of residents, pupils and schools), National Examination Centre (number of persons taking Mathematics exam and its results) and Register of Legal Acts (orders of the Minister of Education) were used for the research. The quantitative data were processed by Excel programme of MS Office software using the methods of statistical analysis of data: descriptive statistics and graphical illustration. The method of content analysis was applied for the qualitative data.

\section{Results and Discussion}

The number of the Lithuanian residents started decreasing in 1992 and the speed of decline of the Lithuanian population is not getting slower (Stankūnienè, Jasilionis \& Baublytè, 2014). The decreasing number of the residents in the country has a direct impact on the number of school-age children (Petkus \& Karaliun, 2014). With regard to territory, the scope of decreasing number of pupils differs, but the difference between the schools in urban and rural areas is evident. The pupils, who acquire primary education in rural areas, go to cities for secondary education. The data of the first table shows how the number of educational institutions and pupils in the country is decreasing every year. However, although the number of pupils is getting smaller every year, we can be happy about the fact that decrease has been reduced twice in 2016 if compared to 2010.

The decreasing number of pupils leads to making schools smaller. Several schools have to be closed in the country every year. The schools are closed with reference to the principle of pupil's basket for rural and small schools, approach of equal educational opportunities, and distinctiveness of the school.

The number of schools in the country is decreasing because of the newly formed concept that the school is the provider of educational services working for the fee of pupil's basket. This causes competition between the educational institutions. As the school has become an institution providing services, it has to attract clients and thus the schools are forced to search for methods how to attract as big number of pupils as possible. The availability of exclusive educational direction became such an opportunity, as it could be attractive and acceptable to pupils and their parents, could help to maintain higher number of pupils and could provide advantage in the municipality with regard to other schools of the same type. The search for such possibilities has expanded the supply of fields

Table 1

\section{Number of the Lithuanian schools and pupils and its change}

\begin{tabular}{|c|c|c|c|c|}
\hline Year & $\begin{array}{c}\text { Number of schools in } \\
\text { the country }\end{array}$ & $\begin{array}{c}\text { Number of pupils in } \\
\text { the country }\end{array}$ & $\begin{array}{c}\text { Change in the number } \\
\text { of schools, } \%\end{array}$ & $\begin{array}{c}\text { Change in the number } \\
\text { of pupils, } \%\end{array}$ \\
\hline 2016 & 1193 & 335202 & & \\
\hline 2015 & 1200 & 344721 & $-0.58 \%$ & $-2.76 \%$ \\
\hline 2014 & 1208 & 357530 & $-0.66 \%$ & $-3.58 \%$ \\
\hline 2013 & 1242 & 373874 & $-2.74 \%$ & $-4.37 \%$ \\
\hline 2012 & 1309 & 392922 & $-5.12 \%$ & $-4.85 \%$ \\
\hline 2011 & 1321 & 415873 & $-0.91 \%$ & $-5.52 \%$ \\
\hline 2010 & 1364 & 440504 & $-3.15 \%$ & $-5.59 \%$ \\
\hline
\end{tabular}


and specializations for the market of educational services, so now the parents may take their offspring to the following schools:

Catholic schools;

Schools of arts (fine arts, music);

Schools of special needs;

Schools engaged in natural protection;

Resort schools;

Schools of law and soldiership;

Boarding schools (for ones, who have disorders of movement or position);

University gymnasiums;

Sport and wellness schools.

Regardless of the school's specification, the programme of secondary education has to be implemented. One of the parts of the programme of secondary education is education of Mathematics. According to the theory of generations of the American scientists Neil Howe and William Strauss, we are educating children of generation $\mathrm{Z}$ right now. They are characterized by technological sophistication, hyperactivity, disobedience, impatience, individualism, laziness, consumerism, tendency to look deeper inside oneself and virtual world leaving the live communication and other information channels besides Internet aside (Alonderine, 2015; Targamadzè, 2014). The generation $\mathrm{Z}$ is able to control information, process it faster but in smaller amounts, if compared to previous generations. They observe more sources of information, read superficially, concentrate attention briefly and cannot write correctly. It is difficult to get the generation $\mathrm{Z}$ interested in any activity, especially if it is not directed to modern technologies. If we know the learning difficulties of the children, we can work systematically and start influencing them by choosing appropriate strategy. New learning technologies should be included into teaching, for example, traditional board in class should be replaced by interactive board; we should teach them to find information, to work with it and use in real life, and to avoid mechanical memorization of information. The information provided by the teacher has to be well weight, brief and accurate, presented creatively, playfully, including symbols or emoticons to the text. The work in groups and exchanging of teaching/learning activities should be encouraged during the lessons.

Infantilization is strongly expressed among persons of generation Z (Targamadze, 2014). Infantilization is especially clear in the mathematical education. It is determined not only by features characteristic to the generation $\mathrm{Z}$, but also by the policy of educational system. The Lithuanian policy of education changed most in 2000 when the profile education was started (humanitarian, real, artistic and technological) in the $11^{\text {th }}$ grade (Ministry of Education and Science of the Republic of Lithuania, 2005). The essence of this education is to organize teaching with regard to the pupils' objectives, tendencies to reduce the studying load, to concentrate on the subjects necessary to choose the studies. As the expectations were not met, in 2007 the Ministry of Education started providing the secondary education not according to the model of profile teaching, but according to the description of secondary education programme (order of the Minister of Education: Changed Description of the Programme of Secondary Education, 2006). The previous profiles were replaced by individual curricula, which are prepared by each pupil individually. Mathematics is one of the subjects that is compulsory for all the pupils, but the learning level may be chosen. The reform of higher education of the year 2009 affected learning of Mathematics a lot. It reduced the number of State-funded places in higher education school and created possibilities for the students to study for their own account. The requirements for entrants were also reduced. The higher education schools were invaded by the students, who had not taken exam of Mathematics and had minimal grades in Mathematics. The universities encountered the problem of qualitative teaching of Mathematics - the number of students not ready to study Mathematics at university increased (Norvaiša, 2012).

The Ministry of Education found a method how to improve the level of mathematical skills among the pupils and the students without changing the essence of the description of secondary education programme: the Minister of Education and Science adopted the order about compulsory exam of Mathematics from 2016 on the $31^{\text {st }}$ of July 2014 (order of the Minister of Education and Science of the Republic of Lithuania, 2014). The order of the $12^{\text {th }}$ of August 2015 was used to set minimal indexes of studying results for the persons applying to the State-funded places to the studies of the first cycle and integrated studies. These indexes were coordinated with higher education schools, National Examination Centre, representatives of students and pupils. It is stated in the order that the persons, who acquire secondary education in Lithuania in 2016 and 2017 and apply for the Statefunded places to the studies of the first cycle and integrated studies will have to take the national final exam of Mathematics, when they apply to college and university study programmes of any field, except for arts (an order of the Minister of Education and Science of the Republic of Lithuania, 2015). The persons, who acquire secondary education in Lithuania in 2018 and apply for the State-funded places to the studies of the first cycle and integrated studies will have to take the national final exam of Mathematics, when they apply 
Achievement level of the exam of Mathematics according to the study areas

\begin{tabular}{|l|l|}
\hline $\begin{array}{l}\text { Achievement level of the national } \\
\text { final exam of Mathematics }\end{array}$ & \multicolumn{1}{|c|}{ Study area } \\
\hline \multirow{3}{*}{ Not lower than satisfactory } & $\begin{array}{l}\bullet \text { Humanities } \\
\text { - Art Pedagogy } \\
\text { - Subject's Pedagogy (if attributed to the area of Humanities) }\end{array}$ \\
\hline \multirow{3}{*}{ Not lower than basic } & $\bullet$ Social Sciences (except for Art Pedagogy and Subject's Pedagogy, \\
& which subject is attributed to the area of Humanities) \\
& $\bullet$ Biomedical Sciences \\
& $\bullet$ Physical and Technological Sciences \\
\hline
\end{tabular}

to college and university study programmes of any field, except for arts, on certain level (Table 2).

The achievement level of the national final exam of Mathematics depends on the number of points collected during the exam. The example is provided in the third table, how the achievement level in Mathematics is determined according to the collected points of exam of Mathematics, when the maximum achievable number of points is 62 .

When the tasks for compulsory national final exam of Mathematics were prepared, the decision was taken to make the passing level lower with regard to the entrance data of the year 2015 and the fact that the pupils were not able to get prepared for the compulsory national final exam of Mathematics in two years properly. The fourth table shows the data on annual number of pupils, who have been taking national final exam of Mathematics, since 2010. It is evident that the number of pupils taking national final exam of Mathematics was significantly decreasing until 2013, while in 2013-2015 similar number of pupils chose to take this exam. In general, until 2016 only some 40 percent of the senior pupils were taking national final exam of Mathematics. However, in the first year when the national final exam of Mathematics became compulsory, the percentage grew up to 55 percent.

Although the number of pupils taking national final exam of Mathematics was decreasing remarkably, the number of failed pupils was growing (Figure 1). In 2014 the pupils, who failed national final exam of Mathematics, made 11.92 percent.
This index was the trigger that forced return to the times when the Mathematics exam was compulsory. The pupils are learning Mathematics at school in general or expanded course. The exam's tasks are prepared in such a way that the national final exam of Mathematics could be passed even by the pupils studying in general course, because 40 percent of the exam's points consist of tasks from general course. Their share is in compliance with minimal requirements of the programme of the national final exam of Mathematics. In 2016 the percentage of pupils who had not passed the national final exam of Mathematics was bigger than in 2015, but it cannot be forgotten that the exam became compulsory after a long period. Not only the well-prepared pupils took the exam, but also the pupils, who did not want to lose a possibility to apply for the State-funded place. The National Examination Centre announces the examination tasks of Mathematics and other subjects in every January-February. The schools may try them as trial tasks and help the pupils to self-assess their knowledge and to choose the exams properly.

After introduction of the compulsory national final exam of Mathematics the schools try to help the students to consolidate their knowledge. The Mathematics modules - additional lessons, for which separate programmes are written, are offered to the pupils of the $3^{\text {rd }}$ and $4^{\text {th }}$ gymnasium grades. These programmes may be of two types - to deepen skills or to eliminate gaps. All the Lithuanian schools are using this methodology to help the pupil. One school - Lyceum of Cadets of General

Table 3

Achievement levels of the national final exam of Mathematics

\begin{tabular}{|c|c|c|c|c|}
\cline { 3 - 4 } \multicolumn{2}{c|}{} & Satisfactory & Basic & Superior \\
\hline Collected points & $0-9$ & $10-25$ & $26-48$ & $49-62$ \\
\hline Evaluation & Failed & $16-35$ scores & $36-85$ scores & $85-100$ scores \\
\hline
\end{tabular}




\section{Number of pupils taking national final exam of Mathematics}

\begin{tabular}{|l|c|c|c|c|c|c|c|}
\hline Year & 2010 & 2011 & 2012 & 2013 & 2014 & 2015 & 2016 \\
\hline Pupils & 21150 & 19690 & 16867 & 15139 & 15610 & 15282 & 17621 \\
\hline
\end{tabular}

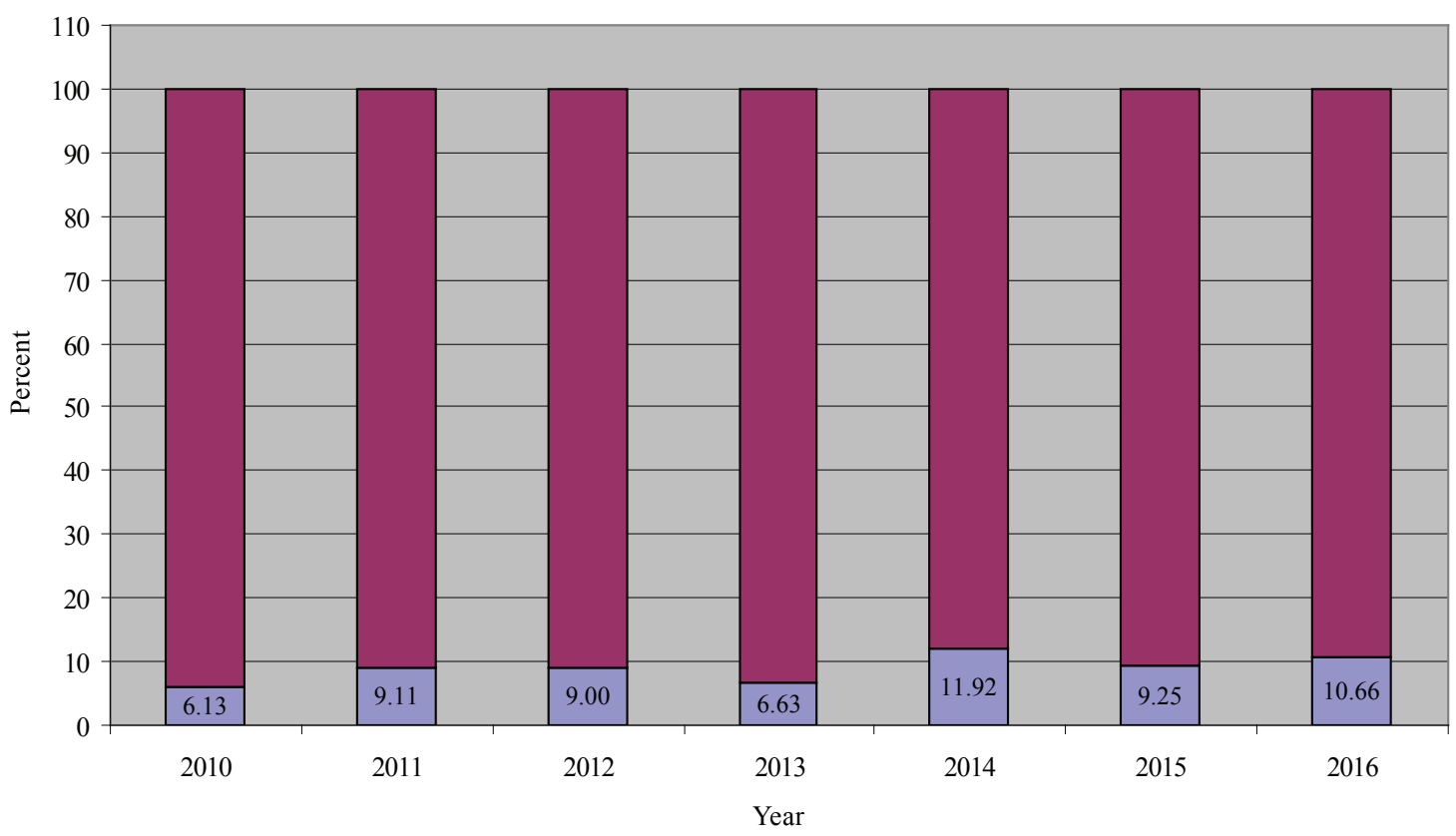

Figure 1. Results of final exam of Mathematics.

P. Plechavičius - is applying one additional methodology - self-preparation with the subject's specialist. Self-preparation means time given to the pupils to do their homework at school. The school's management has obliged to appoint the teachers of main subjects to supervise self-preparation of the pupils of the $3^{\text {rd }}$ gymnasium grades, so that the pupils could be consulted if necessary. The pupils, who find help of the school insufficient, have an alternative - a tutor. However, that is already business of pupils.

One more problem is textbooks. The researches on textbooks in Lithuania have been scarce. Some of the textbooks contained in the textbook data system are not in compliance with the present requirements of secondary education programmes any more, so the textbooks issued before 2005 are rarely used (only as additional literature). At present senior pupils in Lithuania are taught Mathematics according to two different series of the textbooks most frequently (Mathematics for You, Mathematics Expanded Course), while from the next year they will be able to choose from three different series (Mathematics for You, Mathematics Expanded Course, Mathematics tempus) (Report on present situation of textbooks of general education, 2014). The textbooks differ by the layout of topics and complexity of exercises. Each school makes individual decision what textbook to choose, but the exam of Mathematics is the same in the entire country, regardless of the textbook used for education. The study achievements depend on the properly selected textbook (Sičiūnienè \& Dargytė, 2010).

\section{Conclusions}

1. The decreasing number of residents reduces the number of pupils and some schools have to be closed.

2. The attribution of school to the group of service providers, in this case provision of educational services, induces competition between the schools with objective to attract as many pupils as possible.

3. If we know the features characteristic to the generation $\mathrm{Z}$, their learning difficulties, if we choose a suitable teaching and communicating methodology, we will be able to raise the mathematical literacy and reduce the infantilization. 
4. Schools attempt to help the pupils to learn Mathematics better by using various methods: they offer models and self-preparation with a specialist.

5. There is too much freedom of choice with regard of the learning level of Mathematics and exam prevented from learning minimal skills of the subject.

6. It is probable that the changed requirements for the persons, who apply for State-funded study programme, and the compulsory exam of Mathematics will induce more responsible learning of Mathematics, to choose the areas of physical and technological sciences, will raise the mathematical literacy of the pupils, and despite the decreasing number of pupils, will increase the number of persons, who take national final exam of Mathematics, so more people having basic mathematical skills necessary for selected studies will reach universities.

\section{References}

1. Alonderinè R. (2015, January). Kartų skirtumai, arba kas ateis po kartos Z (Differences between Generations or who will come after the Generation Z) Retrieved September 02, 2016, from http://www.bernardinai.lt/straipsnis/20150 1-06-kartu-skirtumai-arba-kas-ateis-pokartos-z/125990. (in Lithuanian).

2. Lileikienè-Giedraitienè, T., Žilvienè, R. (2002). Tobulejimo linkme. Matematikos mokytojų patirtis (Development direction. Math teachers experience). Vilnius, Lithuania: publishers association BIBLION. (in Lithuanian).

3. Lithuanian Statistics Department. (2016, September). Lietuvos mokyklos ir mokiniai. (Schools and students in Lithuania). Retrieved September 05, 2016, from http://www.stat.gov. 1t/. (in Lithuanian).

4. Ministry of Education and Science of the Republic of Lithuania. (2005). Profilinio mokymosi problemos (Problem of Profile Learning). Retrieved September 03, 2016, from
www.smm.lt/uploads/documents/kiti/Profilinio ataskaita_doc. (in Lithuanian).

5. National Examination Centre. (2016). Mokiniu matematikos egzamino rezultatai (Students results in math exams). Retrieved September 05, 2016, from http://www.nec.1t/590/. (in Lithuanian).

6. Norvaiša, R. (2012). Matematikos mokymas laike ịstrigęs pasaulis. (Teaching of Mathematics - World stuck in Time). Retrieved September 05, 2016, from http://norvaisa.lt/wp-content/ uploads/2012/07/laike-istriges-pasaulis.pdf. (in Lithuanian).

7. Pečiuliauskienė, P., Valantinaitè, I., Malonaitienè, V. (2013). Z karta: kūrybingumas ir integracija (Generation Z: Creativity and Integration). Vilnius: Edukologija. (in Lithuanian).

8. Petkus, T., Karaliun, I. (2014). Mokytojų poreikio tyrimas. (Research of Teacher's Demand.) Works of the Lithuanian Mathematician Society, $55 \mathrm{t}$, p. 100-104. ISSN 0132-2818. (in Lithuanian).

9. Sičiūnienė, V., Dargytė, J. (2010). Alternatyvių matematikos vadovèlių poveikis šeštokų mokymosi pasiekimams (Impact of Alternative Textbooks of Mathematics on the Study Achievements of Sixth-Graders). Pedagogy, p.92-97. ISSN 1392-0310. (in Lithuanian).

10. Stankūnienè, V., Jasilionis, D., Baublytè, M. (2014). Lietuvos demografinis kelias: praeities ir lyginamoji perspektyvos (Lithuanian Demographical Road: Past and Comparative Perspectives). VDU Demographic research center: Demography for All, No. 01, p. 3-8. ISSN 2351-6887. (in Lithuanian).

11. Strauss, W., Howe, N. (1992). Generations: The History of America's Future, 1584 to 2069. New York: William Morrow Paperbacks.

12. Targamadzé, V. (2014). Z karta: charakteristika ir ugdymo metodologinès linkmès įžvalga (Generation Z: Characteristic and Insight of Methodological Direction of Education.) Bridges, №. 04, p. 95-104. ISSN 1392-3137. (in Lithuanian). 